\title{
COMMON VALUES OF THE MILITARY ORGANIZATION AND OF THE FIELD OF PHYSICAL EDUCATION AND SPORT
}

\author{
Lt.Col.Sup.Instr. Marius Constantin ISTRATE, PhD Candidate* \\ Col. (ret) Prof. Ion BĂLĂCEANU, PhD**
}

\begin{abstract}
The military organization, due to its fundamental role in defending and maintaining the sovereignty and security of any state in the world, has undergone a natural evolutionary process. In this process man plays the main role. Thus, the continuous transformation to which the military organization was and is still subjected to, being permanently conditioned by the constantly changing threats and challenges, was achieved simultaneously with human evolution, under the impact of all discoveries and technologies developed and implemented by it. In this article, we will analyze two important areas of human activity, military organization and sports, focusing on finding common values for the two areas and generating relevant answers to the question: Is a sports team equivalent to a military structure?
\end{abstract}

Keywords: military organization; physical education and sports; common values; connections.

The fulfillment of the specific missions of education process that systematically capitalizes on the military organization is based on a unitary all forms of collective or individual activity, which process, very complex training, in which all its component elements (theoretical, tactical, technical, psychological, etc.) have well-established roles, being closely linked and interdependent. The key element that makes the connection between all these components of the military training process is, of course, the human resource. Therefore, simultaneously with the structural, conceptual and methodological transformations to which the military organization is subjected, the main emphasis must be on the development of human resources, on finding viable solutions for the training and instruction of valuable fighters, capable of any sacrifice, with qualities, skills, abilities and practical skills needed to meet challenges of any kind. Thus, in order to fulfill the main mission of the military organization, "achieving supremacy and victory in any type of armed confrontation", we consider that the modernization and reform of the current military physical education system is one of the most viable and easily accessible solutions, taking into account the fact that military physical education is "a fundamental component of the instruction /

\footnotetext{
*"Carol I" National Defence University e-mail: mariusconstantinistrate@yahoo.com **"Carol I" National Defence University e-mail:balaceanuion@yahoo.com
}

\section{Historic aspects of the connection of military education with physical education and sport}

There has always been an indissoluble link between the military organization and physical education, the two being institutions whose activities have been permanently intertwined and even confused. The interference between the military organization and the field of physical education and sports, a field that includes a wide range of systematic activities of physical training, physical education and sports competitions, goes down in the mists of time, to ancient times, especially in Greek civilization, which was very concerned with the cultivation of physical and moral beauty, virtues, followers of competitions, the cult of city heroes, heroes - winners of the Olympic Games or winners on the battlefields ${ }^{3}$.

The connection between the military organization and the field of physical education also results from the fact that, in the past, there 
were significant periods of time when all disputes were resolved by force, armed conflict, and the strength and physical endurance of fighters was decisive, tipping the balance of the final victory to one side or the other. Therefore, the military commanders were always interested in the training and physical condition of the soldiers they had available. Moreover, with a few exceptions, kings, emperors or rulers of different cities, state entities or even empires of those times had to prove that they were strong, that they completely mastered the technique of weapons, their attitude and qualities being the psychological factor that determined the armies to sometimes follow even to the ultimate sacrifice. They prove that, throughout history, throughout its development, physical education has had a military and political determination and thus, has been highlighted by a strong military character, integrating perfectly into the training process necessary for training and the conduct of the war.

Gradually, with the development of modern society, at the end of the eighteenth century and the beginning of the nineteenth century, the transition was made from empirical exercises, not very organized, to complete physical education systems, organized on a scientific basis and on general pedagogical conceptions adapted to the political realities and social characteristics of the states of that period. Basically, by setting up specialized institutions in this field (Gymnastics Society in 1799, respectively the Institute for Military Gymnastics in 1804 in Copenhagen - Denmark, the Royal Gymnastics Institute in Stockholm Sweden in 1813, the Durdan Institute in Paris in 1817, the Amateur Athletic Club from London England in 1866) they signed the birth certificate of the modern system of physical education. The vast majority of those who, through their work and efforts, reformed this activity, came from the military organization or had a close connection with it (Spanish Colonel Don Francesco Amoros y Ondeano in France, Friedrich Ludwig Jahn in Germany - participant in the liberation war as a volunteer in the Prussian army, Franciscus Nachtegall in Denmark - professor and director of the Institute for Military Gymnastics, etc.). These illustrious promoters of physical education fully understood the fundamental role that good physical training plays in the development of societies and nations as a whole, thus succeeding in introducing this discipline into curricula and thus contributing to the education of the younger generation which represents the future of any nation.

Inourcountry,too,physicaleducationdeveloped with the contribution of career soldiers: General Dr. Carol Davila, officers Justin Mărginean and Virgil Bădulescu, supported by His Royal Highness Prince Carol and the military commanders of those times (General Grigore Crăiniceanu - Minister of War, General Constantin Herjeu - Chief of the General Staff, etc.). Of all those who militated and participated directly in the development of this activity, the founder of the modern system of physical education in our country, unanimously recognized, is General Virgil I. Badulescu. He, in addition to the deeds of bravery he performed with mountain troops in the First World War (he founded and commanded the first battalion of mountain troops in the Romanian Army at the head of which, he won resounding victories in the battles of Cosna and Cireșoaia ${ }^{4}$ ), dedicated his entire career and life to physical education.

The contribution he had to the development of this activity is impressive: he brought and implemented in the education system of our country one of the most complete physical education systems at that time, namely the Swedish model; participated directly, coordinated and led the establishment of the first bodies and institutions specialized in this field (Military School of Fencing and Gymnastics - 1913, National Office of Physical Education 1922, National Institute of Physical Education - the first university institution-1922, Military Institute of Physical Education - 1929); he was the initiator of the first project for what would become the first law of physical education in Romania, the Law for physical education - 1923 and later, he contributed to its improvement which was transformed in 1929, into the Law of physical education; effectively contributed to the development of the material base and the construction of the first facilities specific to this activity (the first stadium in Romania - the ONEF stadium, the ONEF training ground, the sports complex and the swimming pool in the Eforie resort, etc.); he wrote the first specialized instructions, manuals and regulations, edited the first physical education magazine "Izvor de energie" in $1921^{5}$ and had a truly remarkable contribution to the development of scientific research in this field. 
Thus, eloquent for the connection between his two passions, namely military organization and physical education, he said: "In all times and everywhere these two notions have been mistaken one for the other and could not be separated from each other without taking a step backwards or representing a danger"6.

In conclusion, the historic aspects presented in the first part of our study highlight the need and importance of physical education and sports and military education, the two areas having historical connections, intertwining and complementing each other, both helping to achieve educational goals and to obtaining beneficial results for the human being.

\section{Is a sports team the equivalent of a military structure?}

After this period of beginnings, of searches and settlements, the physical education system followed its natural course, nowadays reaching a high level of development, the research and promotion of this field no longer being the exclusive prerogative of the military. However, the influence due to the military origin of physical education and the specific elements of this origin will not disappear, and the link between the military factor and the physical education system will last forever. In other words, and in the context of our research, between the military organization and the specific field of physical education and sports there are many similarities and common elements, starting with the organization of activities and reaching the common values that both promote.

Within the physical education class, which represents the "main organizational and functional unit of the instructive-educational process"7, the way of organizing and carrying out the activity kept the typical military character. Thus, the workings in line in threes, in line in a row, in columns one by one, etc., as well as the positions, front movements and front and training exercises with which the physical education lesson usually begins are largely the same as in military training. The same characteristics of the coat of arms wear part of the terminology and commands used by the teacher or instructor during the physical education class.

The organization of the activity in workshops is another common element, each workshop being coordinated by a person in charge (instructor). This person in charge is well trained before starting the activity by the physical education teacher, respectively by the subunit commander in the case of the military organization, throughout the activity also bearing the responsibility for its development in good and safe conditions.

There is also a similarity between respecting the rules of employment in the case of military actions, rules provided in International Humanitarian Law and sports fair play, both promoting a fairrelationship between combatants: respect for fundamental human rights, cultivating respect for oneself and opponents, compliance with laws, regulations and customs, as well as setting clear limits during the conduct of these activities. Moreover, in sports activities we find most of the elements characteristic of military art, military tactics, forms of action specific to conducting military operations such as attack, defence, counterattack, harassment, through which the military seeks to successfully complete combat missions and athletes achieve goals. performance and competitive ones.

A sports team is equivalent to a military structure. Thus, the choice of a good strategy by the commander (coach or manager in sports), its permanent adaptation according to the opponent's response, as well as the observance exactly by the military (players) of the tactical plan, are solid premises for victory. Moreover, both on the battlefield and in the sports arena, the fighters constantly aim to dominate their opponent, to knock him to the ground, to defeat him. The major difference is that unlike sports confrontations, at the end of which opponents stand up and shake hands and congratulate each other, in the case of military confrontations, things are not the same, many of the fallen no longer having a chance to get up.

The specific activities of this field, in addition to biological purposes, positively influence the psychological and social sphere, educate the character traits and will of individuals (courage, firmness, ambition, honesty, emulation, perseverance) and their social qualities (team spirit, commitment, solidarity, tolerance, camaraderie). All these qualities and traits of individuals enhance the specific values of the military organization, such as body spirit and cohesion, increase the morale and motivation of the military, essential elements for success in combat. In military structures where the degree of cohesion is high, the military fights 
and coordinates much better, is trained to high standards, cooperates and coordinates very well, does not give up mentally so easily and endures stress for a long time ${ }^{8}$.

The fundamental role that the activities specific to the field of physical education and sports have within the military organization is underlined in the Concept of physical education and sports in the Romanian Army. Thus, "military physical education is the starting point of the entire process of preparation for combat, the pivot of the other components of training, which determines the performance of the military in carrying out combat missions and the efficiency of peacetime activities"9.

\section{Conclusions}

Throughout history, military education and physical education and sport have evolved together, inextricably linked, as two intertwined areas, sometimes confused because both concepts had multiple similarities and promoted similar values;

Throughoutits development, physicaleducation has had military and political determinations, has been highlighted by a strong military character, integrating perfectly into the training process necessary for training, planning and conducting war;

It is unanimously acknowledged that the field of physical education and sport is one of the most important components of lifelong learning, with a special contribution to the training and education of people of all ages, in their growth, personal development and professional completion;

The activities of the field of physical education and sports contribute to the amplification and consolidation of the values of the military organization, as well as to the education and improvement of the physical and mental qualities of the military;

The military origin of physical education and the specific elements of this origin will not disappear, because the connection between the military system and the physical education system will last forever.

\section{NOTES:}

1 A. Pelmuş, Military physical education - past, present and perspectives, "Carol I" National Defence University Publishing House, Bucharest, 2019, p. 5.

2 *** Military Physical Education Regulations, Army Technical-Editorial Center, Bucharest, 2013, p. 7.

3 A. Petrache, Sport and the Army, Military Publishing House, Bucharest, 2013, p. 11.

4 C.F. Nicolescu, Forgotten pages from the history of physical education, Encyclopedic Publishing House, Bucharest, 2014, p. 33.

5 P. Dungaciu, Virgil Bădulescu, founder of ANEFS, 120 years since his birth, Library of the National Academy of Physical Education and Sports, Bucharest, 2002, pp. 6-9.

6 D. Bâsceanu, Army and sport, Military Publishing House, Bucharest, 1997, p. 31.

7 *** Military Physical Education Regulations, Army Technical-Editorial Center, Bucharest, 2013, p. 10

8 http://www.resboiu.ro/coeziunea-la-grup-si-spiritulde-corp/, accessed on 02.03.2021.

$9 * * *$ The concept of physical education and sports in the Romanian Army, General Staff, Bucharest, 2016, p. 8

\section{REFERENCES}

*** Military Physical Education Regulations, Army Technical-Editorial Center, Bucharest, 2013.

*** The concept of physical education and sports in the Romanian Army, General Staff, Bucharest, 2016.

Bâsceanu D., Army and sport, Military Publishing House, Bucharest, 1997.

Dungaciu P., Virgil Bădulescu, founder of ANEFS, 120 years since his birth, Library of the National Academy of Physical Education and Sports, Bucharest, 2002.

Nicolescu C.F., Forgotten pages from the history of physical education, Encyclopedic Publishing House, Bucharest, 2014.

Pelmuș A., Military physical education past, present and perspectives, "Carol I" National Defence University Publishing House, Bucharest, 2019.

Petrache A., Sport and the Army, Military Publishing House, Bucharest, 2013.

http://www.resboiu.ro/coeziunea-la-grup-sispiritul-de-corp/ 